\title{
The distribution and seasonal variations of sedimentary organic matter in the East China Sea shelf
}

\author{
Fengxia Zhou ${ }^{\mathrm{a}, \mathrm{b}}$, Xuelu Gao ${ }^{\mathrm{a}, \mathrm{c}, *}$, Huamao Yuan ${ }^{\mathrm{c}, \mathrm{d}, \mathrm{e}}$, Jinming Song, ${ }^{\mathrm{c}, \mathrm{d}, \mathrm{e}}$, Fajin Chen ${ }^{\mathrm{b}}$ \\ ${ }^{\text {a }}$ CAS Key Laboratory of Coastal Environmental Processes and Ecological Remediation, Yantai Institute of Coastal Zone Research, Chinese Academy of Sciences, Yantai, \\ Shandong 264003, China \\ ${ }^{\mathrm{b}}$ Guangdong Province Key Laboratory for Coastal Ocean Variation and Disaster Prediction Technologies, Guangdong Ocean University, Zhanjiang, Guangdong 524088, \\ China \\ ${ }^{\mathrm{c}}$ University of Chinese Academy of Sciences, Beijing 100049, China \\ ${ }^{\mathrm{d}}$ CAS Key Laboratory of Marine Ecology and Environmental Sciences, Institute of Oceanology, Chinese Academy of Sciences, Qingdao, Shandong 266071, China \\ e Function Laboratory of Marine Ecology and Environmental Sciences, Qingdao National Laboratory of Marine Science and Technology, Qingdao, Shandong 266237, \\ China
}

\section{A R T I C L E I N F O}

\section{Keywords:}

East China Sea shelf

Stable carbon and nitrogen isotopes

Spatial and temporal distribution

Sedimentary organic matter

\begin{abstract}
A B S T R A C T
We sampled the surface sediments of the East China Sea shelf (ECSS) in spring and autumn, 2014, and analyzed the biogenic element concentrations and stable carbon $\left(\delta^{13} \mathrm{C}\right)$ and nitrogen $\left(\delta^{15} \mathrm{~N}\right)$ isotopic compositions to study the distribution and seasonal variations of sedimentary organic matter (OM). The average concentrations of TOC, TN and OP in autumn decreased obviously compared with those in spring. The increase of $\delta^{15} \mathrm{~N}$ values in autumn indicated the priority utilization of ${ }^{14} \mathrm{~N}$ by bacterial decomposition activity. The values of $\delta^{13} \mathrm{C}$ were used to trace organic matter sources. The estimated percentages for terrestrial OM were in the range of 0-34.6\%. They generally decreased seaward in nearshore areas, indicating the decrease of terrigenous influence. There was an obvious tongue-shaped region with relatively low percentages of terrestrial OM $(<12 \%)$ in the northern part of the ECSS, which may be a reflection of the intrusion pathway of the outer seawater.
\end{abstract}

\section{Introduction}

Coastal sediments receive organic matter from different sources, including autochthonous inputs of phytoplankton primary productivity, and allochthonous inputs such as terrigenous, river runoff, and anthropogenic sources (Graham et al., 2001; Lamb et al., 2006). Since organic carbon and nitrogen stable isotope ratios $\left(\delta^{13} \mathrm{C}\right.$ and $\left.\delta^{15} \mathrm{~N}\right)$ and $\mathrm{C} / \mathrm{N}$ elemental ratios of surface sediments from different sources generally have different values, data can be used to identify the organic matter provenance in coastal marine environments $(\mathrm{Vo} \beta$ and Struck, 1997; Ruiz-Fuiz-Fernández et al., 2002; Kubo and Kanda, 2017; Sanil Kumar et al., 2017; Yu and Zhang, 2017). For instance, high $\delta^{15} \mathrm{~N}$ values of $10-14 \%$ may characterize recent river borne particulates (Vo $\beta$ and Struck, 1997), low $\delta^{13} \mathrm{C}$ values of -27.94 to $-26.05 \%$ may indicate terrestrial inputs from higher plants (Sanil Kumar et al., 2017) and $\mathrm{C} / \mathrm{N}$ ratios of 15.13-29.69 may signal a combined input of both autochthonous and terrestrial organic matter sources (Sanil Kumar et al., 2017).

However, values of $\delta^{13} \mathrm{C}, \delta^{15} \mathrm{~N}$ and $\mathrm{C} / \mathrm{N}$ ratios in surface sediments may have seasonal variations due to the influence of primary production or organic matter degradation (Voß and Struck, 1997; Kubo and Kanda, 2017). For example, high winter nutrient concentrations, together with short residence time of water masses in spring, could result in a large fractionation of nitrate during uptake and hence low ${ }^{15} \mathrm{~N}$ in the phytoplankton (Mariotti et al., 1984; Montoya et al., 1990). The settlement of the phytoplankton may then result in seasonal variations of $\delta^{15} \mathrm{~N}$ in the surface sediments. It was reported that seasonal changes in the isotope signal are evident in the surface sediments of the Pomeranian Bight, southern Baltic Sea (Voß and Struck, 1997). Microbial processes can additionally increase ${ }^{15} \mathrm{~N}$ in particles through degradation (Owens, 1985; Cifuentes et al., 1988). For C/N ratios, post-depositional changes could occur, which would result in the inaccuracy of source identification (Meyers, 1994). The $\delta^{13} \mathrm{C}$ values usually increased with increasing productivity (Hodell and Schelske, 1998; Kang et al., 2017). These characteristics of $\delta^{13} \mathrm{C}, \delta^{15} \mathrm{~N}$ and $\mathrm{C} / \mathrm{N}$ may limit their use in the identification of the organic matter provenance (Thornton and MacManus, 1994; Vo $\beta$ and Struck, 1997).

The dispersal of the Changjiang (Yangtze River)-derived and

\footnotetext{
*Corresponding author at: CAS Key Laboratory of Coastal Environmental Processes and Ecological Remediation, Yantai Institute of Coastal Zone Research, Chinese Academy of Sciences, Yantai, Shandong 264003, China.

E-mail address: xlgao@yic.ac.cn (X. Gao).
} 
marine-derived sediments in the East China Sea shelf (ECSS), China, is largely affected by the seasonal hydrodynamics (Li et al., 2014a). The discharge of the Changiiang is highly seasonal with its peak in summer and $75 \%$ of the river runoff occurring during the flood/rainy season between May and October (Rabouille et al., 2008). The Kuroshio Current, which has profound effect on the eco-environment of the East China Sea shelf, generally moves away from the shelf in summer and moves close to and sometimes onto the northern shelf of Taiwan (Tang et al., 2000). Previous studies have shown that terrestrial organic matter $(\mathrm{OM})$ is a critical component of sedimentary OM with its percentages ranging from 5\% to $57 \%$ in the mud regions of the Changjiang Estuary and the adjacent ECSS (Zhang et al., 2007; Xing et al., 2011; Hu et al., 2012; X. Li et al., 2012; Li et al., 2014a). Furthermore, these studies also provide valuable insights regarding the spatial variations, abundance, age as well as burial of sedimentary OM in this dynamic environment. In summary, the valuable insights mainly included the following contents: terrestrial organic matter accounted for an increasing fraction of sedimentary OM seaward in the Changjiang Estuary (Zhang et al., 2007; Xing et al., 2011; Hu et al., 2012; X. Li et al., 2012; Li et al., 2014a); winter wind/wave energy and hydrodynamic sorting had a substantial effect on sediment OM redistribution in the inner shelf of the East China Sea (X. Li et al., 2012); the increasing input of freshwater plankton and eutrophication were important driving forces for carbon cycling in the Changjiang Estuary and its adjacent regions (Li et al., 2014a). However, the sources, distribution and seasonal variations of sedimentary OM in the ECSS remain poorly explored. This paper presented data on $\delta^{13} \mathrm{C}, \delta^{15} \mathrm{~N}$, total organic carbon (TOC), total nitrogen (TN) and related parameters for the surface sediments in the ECSS in spring and autumn and the sources and decay of sedimentary organic matter in this area were also discussed.

\section{Materials and methods}

\subsection{Study area and sample collection}

The ECSS, with moderately high primary production (Gong et al., 2003), is bordered by Chinese mainland on the western side (Fig. 1). It is a dynamic area with tremendous riverine inputs and intense current activities (Fig. 1). The Changjiang is the third largest river in the world in the length and runoff. It is also a major source of materials to the ECSS (Fig. 1; Wu et al., 2004; X. Li et al., 2012). The substantial freshwater input from the Changjiang forms the strong Changjiang
Diluted Water (CDW) (Fig. 1). The Zhejiang-Fujian Coastal Current (ZFCC) flows northward in summer and southward in winter (Su, 2005; Fig. 1). The Taiwan Warm Current (TWC) perennially flows northward (Su, 2005; Fig. 1). The main stream of the KC flows northeastward along the ECSS break (Fig. 1).

The sampling of this research was carried out in May 22-June 11 (spring) and October 18-November 30 (autumn), 2014 on board R/V Science I. The study area extends approximately from the east of Zhoushan Archipelago to the north of the Taiwan Strait with water depths generally $<100 \mathrm{~m}$ (Fig. 1). The top $\sim 2 \mathrm{~cm}$ sediments were gathered with a plastic spatula from the center part of the sampler and were kept in pre-cleaned polyethylene bags. One sample was collected from each station ( 30 stations in spring and 29 stations in autumn) for the analysis of grain size, TOC, TN and stable carbon and nitrogen isotopic compositions. All the collected samples were immediately frozen until further analysis.

\subsection{Analytical methods}

Grain size analysis was carried out by means of a Malvern Mastersizer 2000 laser diffractometer after the removal of the inorganic carbonates using $10 \%(\mathrm{v} / \mathrm{v}) \mathrm{HCl}$ and the organic matter using $30 \%(\mathrm{v} /$ v) $\mathrm{H}_{2} \mathrm{O}_{2}$ (Folk, 1974). The percentages of the following 3 groups of grain sizes were determined: $<4 \mu \mathrm{m}$ (clay), $4-63 \mu \mathrm{m}$ (silt), and $>63$ $\mu \mathrm{m}$ (sand). $20 \%$ of the collected samples were analyzed in replicate and the relative error was $<3 \%$.

A total of 71 freeze-dried samples $(20 \%$ of the collected samples were analyzed in duplicate) were homogenized, thoroughly ground and sieved through a 200 mesh screen. About 200 and $50 \mathrm{mg}$ of each freezedried, homogenized and ground sample were analyzed for TN and $\delta^{15} \mathrm{~N}$, respectively. About $2 \mathrm{~g}$ of each freeze-dried, homogenized and ground sample was weighed and loaded into a $15 \mathrm{ml}$ tube, treated with $1 \mathrm{M} \mathrm{HCl}$ to remove carbonates, and freeze-dried, thoroughly ground again for the analysis of TOC and $\delta^{13} \mathrm{C}$. Concentrations of TN and TOC were determined with an Elementar vario MACRO cube CHNS analyzer. Sulphanilamide was used as the standard reference material and the precision was $0.02 \%$ for TOC and $0.005 \%$ for TN. $\delta^{13} \mathrm{C}$ and $\delta^{15} \mathrm{~N}$ values were obtained using the isotope ratio mass spectrometer (Thermo, MAT 253). $\delta^{13} \mathrm{C}$ was given as \%o-deviation from the isotope composition of the PDB (Pee Dee Belemnite) standard. $\delta^{15} \mathrm{~N}$ was given as \%o-deviation from the nitrogen isotope composition of atmospheric air. The precision was $\pm 0.2 \%$ for $\delta^{13} \mathrm{C}$ and $\pm 0.4 \%$ for $\delta^{15} \mathrm{~N}$. All the laboratory

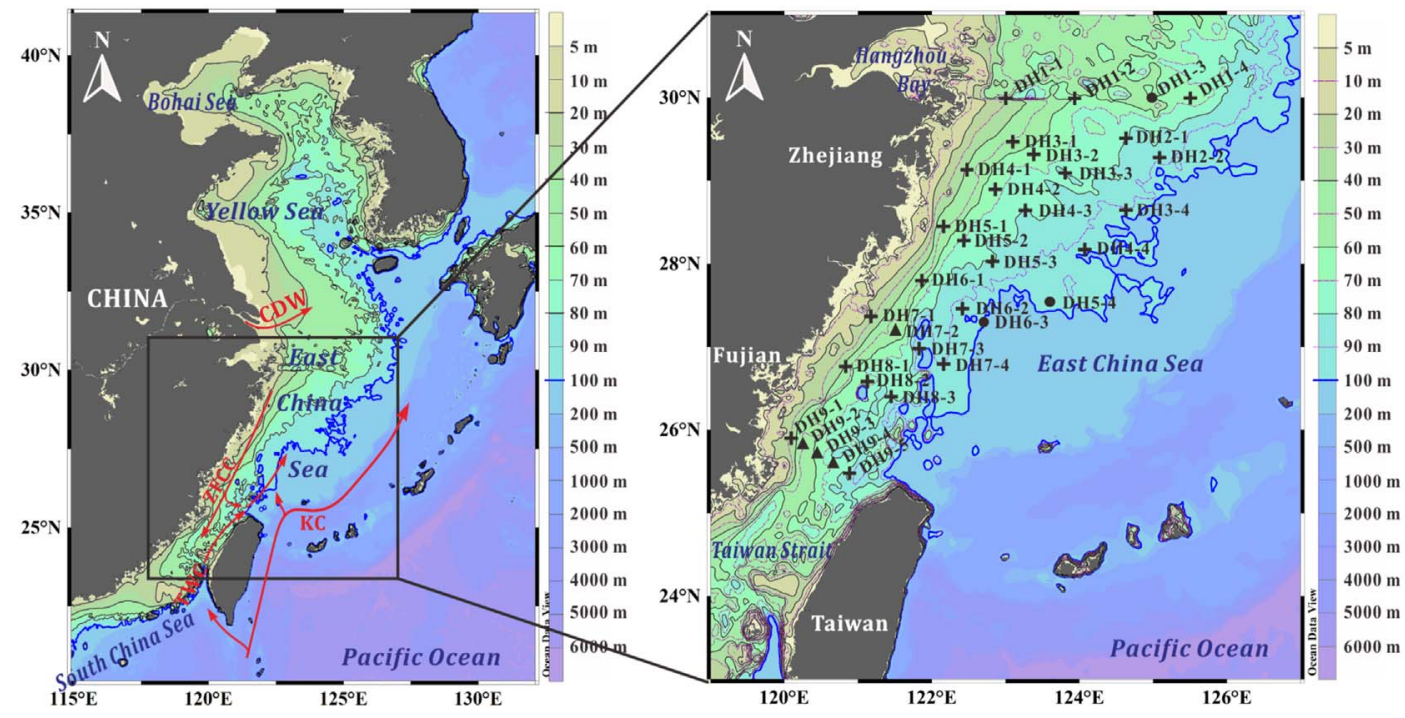

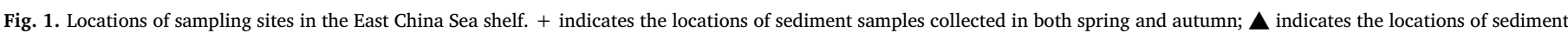

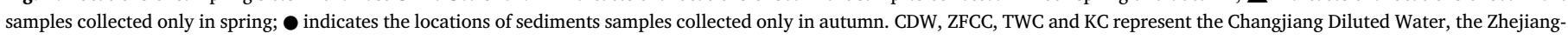
Fujian Coastal Current, the Taiwan Warm Current and the Kuroshio Current, respectively. 

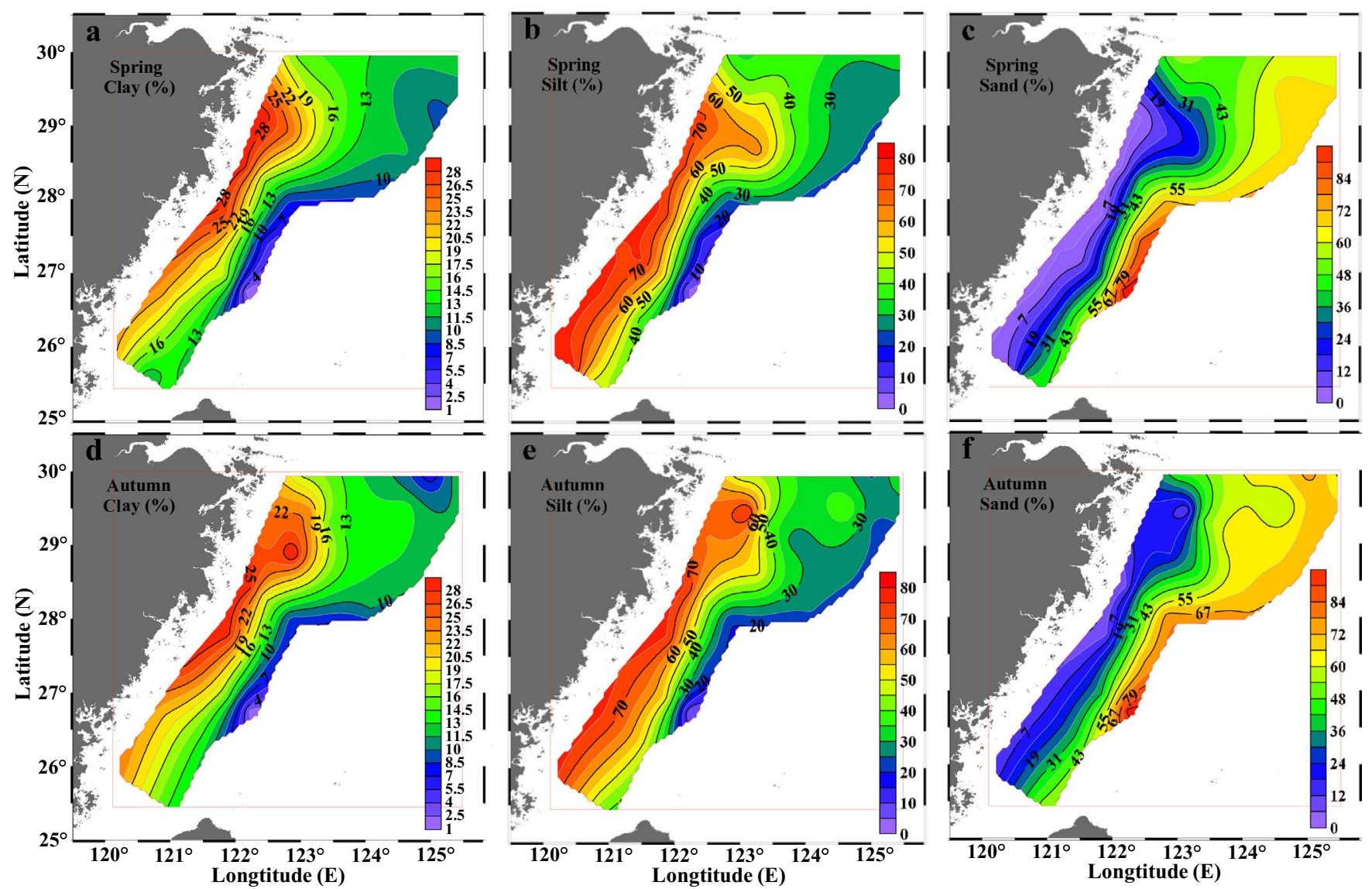

Fig. 2. Spatial variations of clay, silt and sand fractions of the surface sediments in the East China Sea shelf in spring and autumn.

equipment was pre-cleaned by soaking in $10 \% \mathrm{HCl}(\mathrm{v} / \mathrm{v})$ for at least 2 days, followed by soaking and rinsing with de-ionized water. The determination of organic phosphorus (OP) and related results have been given in detail in the study of Zhou et al. (2016).

\subsection{Data treatment and analysis}

Pearson's correlation coefficient was used to test the correlation between variables. A linear regression analysis was conducted to relate TOC and TN. One-way ANOVA was used to determine the differences of the parameters between two seasons. The above-mentioned analyses were performed using the SPSS statistical package version 19.0 (SPSS Inc.).

\section{Results and discussion}

\subsection{Bulk properties of surface sediments}

The grain size compositions of the surface sediments in the ECSS are presented in Fig. 2. A more detailed description of the grain size characteristics in the study area has been provided by Zhou et al. (2016). Briefly, in both seasons, fine-grained sediments (silt and clay) dominated the inner shelf of the ECSS and coarse-grained sediments (sand) dominated the outer shelf of the ECSS (Fig. 2). The percent of the sand fraction showed obvious seasonal variations, with its average value in autumn $19 \%$ higher than that in spring.

In spring, the concentrations of TOC in the surface sediments of the ECSS ranged from $0.15 \%$ to $0.75 \%$ with a mean of $0.54 \%$; in autumn, they ranged from $0.17 \%$ to $0.75 \%$ with a mean of $0.43 \%$ (Fig. $3 a$ and b). The average TOC concentration in spring was $26 \%$ higher than that in autumn. The spatial patterns of TOC in the surface sediments of the
ECSS in spring and autumn were similar to some extent, with relatively high values in the nearshore areas (Fig. $3 a$ and b). In both seasons, the proportions of TOC were positively correlated with \%silt $(0.01<P<0.05)$ and \%clay $(0.01<P<0.05)$ distribution, and negatively correlated with \%sand distribution $(0.001<P<0.01)$. In spring, the concentrations of TN ranged from $0.022 \%$ to $0.151 \%$ with a mean of $0.096 \%$; in autumn, they ranged from $0.027 \%$ to $0.137 \%$ with a mean of $0.077 \%$ (Fig. $3 \mathrm{c}$ and d). The average concentration of TN in spring was $19 \%$ higher than that in autumn. Like the spatial distribution of TOC, relatively high concentrations of TN were found in the nearshore areas of the ECSS in both seasons (Fig. 3c and d). A significant linear relationship existed between TOC and TN in both spring and autumn (Fig. 4), and their intercepts in both seasons were near zero $(0.0069 \%$ in spring and $-0.0011 \%$ in autumn; Fig. 4$)$, indicating that TN was predominantly of organic origin (Goñi et al., 2003). The difference in the concentrations of TOC and TN between spring and autumn suggested that labile organic matter was being decomposed during the investigation period (Andrews et al., 1998).

\section{2. $\delta^{13} C, \delta^{15} N$ and TOC/TN}

Fig. 5 shows the spatial patterns of $\delta^{13} \mathrm{C}$ and $\delta^{15} \mathrm{~N}$ in the surface sediments of the ECSS in spring and autumn. In spring, the values of $\delta^{13} \mathrm{C}$ ranged from $-22.08 \%$ to $-19.99 \%$ with a mean of $-21.35 \%$; in autumn, they ranged from $-21.97 \%$ to $-20.10 \%$ with a mean of $-21.00 \%$. Overall, in both seasons, locations near the coast have more negative $\delta^{13} \mathrm{C}$ values, and the $\delta^{13} \mathrm{C}$ values increased with distance farther offshore (Fig. 5a and b). In spring, the values of $\delta^{15} \mathrm{~N}$ ranged from $3.67 \%$ to $6.28 \%$ with a mean of $4.60 \%$; in autumn, the values of $\delta^{15} \mathrm{~N}$ ranged from $4.60 \%$ to $6.13 \%$ with a mean of $5.32 \%$. The average value of $\delta^{15} \mathrm{~N}$ in autumn was $15 \%$ higher than that in spring, which 

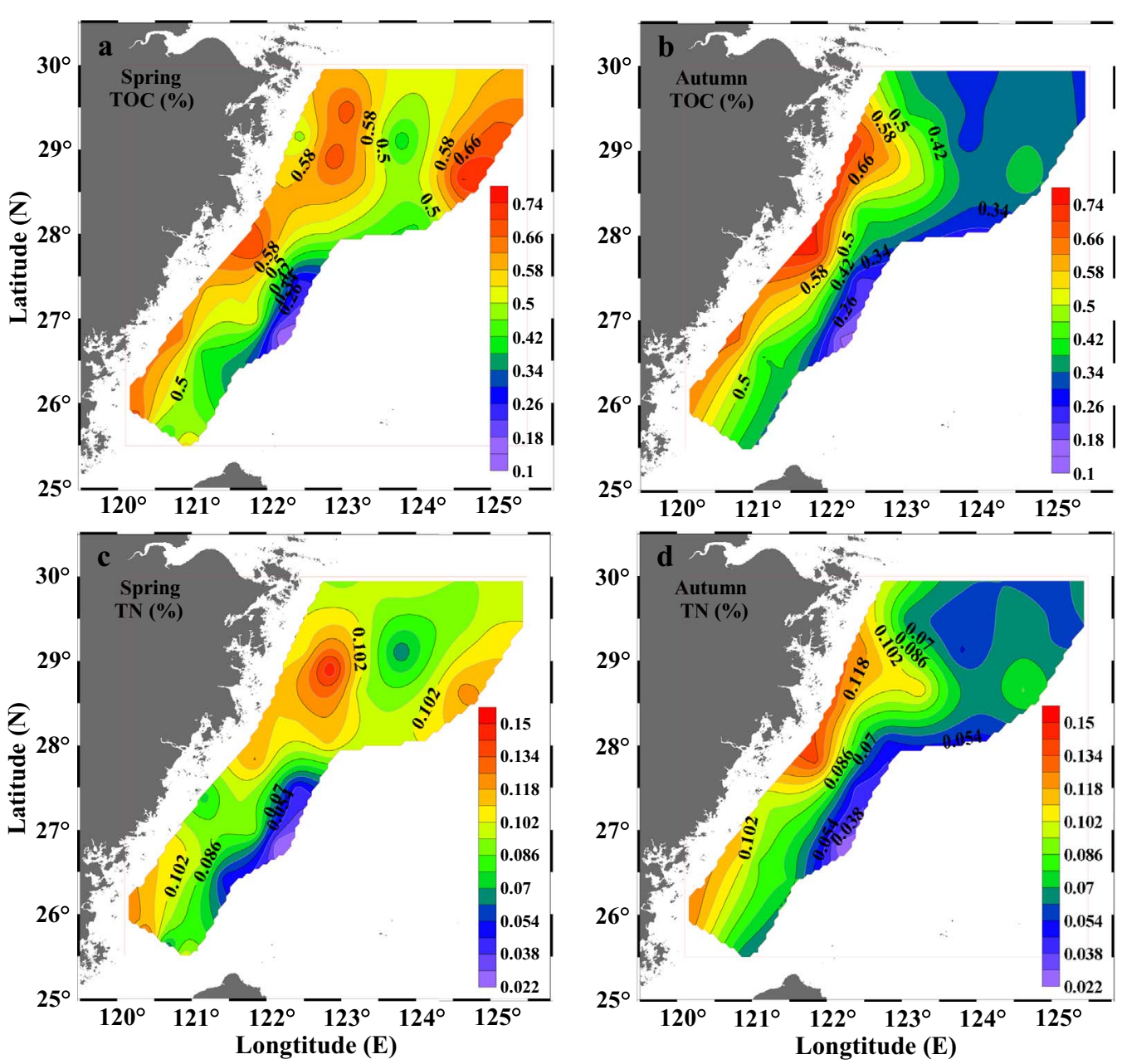

Fig. 3. Spatial distributions of TOC and TN in the surface sediments of the East China Sea shelf in spring and autumn.

presented obvious seasonal variations. In both seasons, relatively high $\delta^{15} \mathrm{~N}$ values were found in the offshore areas of the northern part of the ECSS (Fig. $5 \mathrm{c}$ and d).

Fig. 6 shows the spatial distributions of TOC/TN molar ratios in both seasons. In the whole study area, TOC/TN ratios ranged from 4.69 to 9.12 with a mean of 6.74 in spring and from 4.78 to 8.89 with a mean of 6.73 in autumn. The average values of TOC/TN ratios in both seasons were rather similar. Even in the northern part of the study area, where the average concentrations of both TOC and TN in spring were obviously lower than those in autumn, the average TOC/TN ratios in different seasons were still rather similar (spring: 6.52, autumn: 6.54; $\mathrm{n}=16$ ). This indicated that the decrease of TOC during the

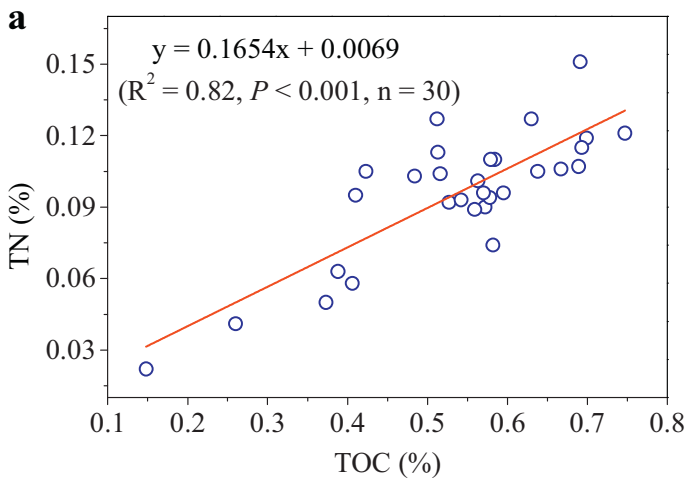

investigation period was proportional to that of TN.

\subsection{Environmental indications of $\delta^{13} C, \delta^{15} N$ and elemental ratios}

The average $\delta^{13} \mathrm{C}$ values of terrigenous C3 and C4 plant are $-27 \%$ (range: $-33 \%$ to $-22 \%$ ) and $-13 \%$ (range: $-16 \%$ to $-9 \%$ ), respectively (Pancost and Boot, 2004; Table 1). The $\delta^{13} \mathrm{C}$ values of marine organic matter range from $-22 \%$ to $-18 \%$ (Cifuentes and Eldridge, 1998; Table 1). Hu et al. (2012) reported that the terrigenous organic matter in the surface sediments of the Changjiang Estuary and its adjacent sea were mostly of terrigenous C3 plant, and the proportion of terrigenous C4 plant was probably rather small. Therefore, based on the

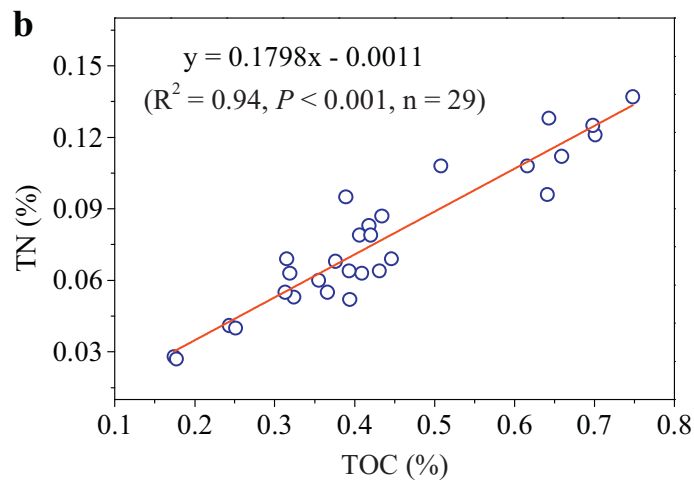

Fig. 4. Relationships of TOC versus TN for the surface sediments from the East China Sea shelf in spring (a) and autumn (b). 

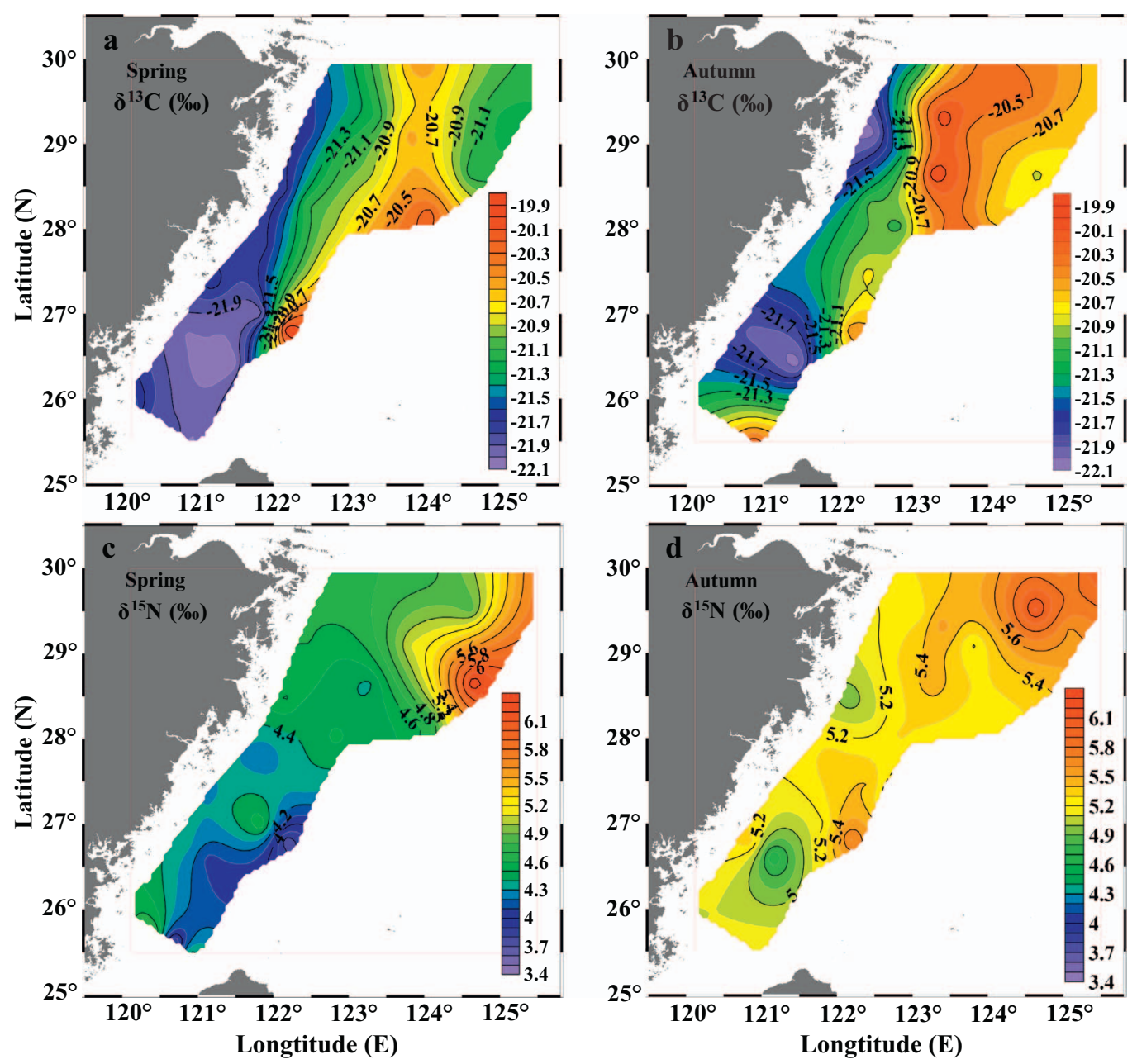

Fig. 5. Distributions of $\delta^{13} \mathrm{C}$ and $\delta^{15} \mathrm{~N}$ values in the surface sediments of the East China Sea shelf in spring and autumn.

values and distribution patterns of $\delta^{13} \mathrm{C}$ obtained in this study, we could conclude that the organic matter in the surface sediments of the ECSS was predominantly marine autogenic and that the nearshore areas of the ECSS were influenced by terrigenous input to some extent (Table 1; Fig. 5a and b). The values of $\delta^{15} \mathrm{~N}$ for marine phytoplankton typically range from $4 \%$ to $10 \%$ with a mean value of $6 \%$, while the values of $\delta^{15} \mathrm{~N}$ for terrigenous organic matter range from $-10 \%$ to $10 \%$ with a mean of 2\%o (Dean et al., 1986; Table 1). The values of $\delta^{15} \mathrm{~N}$ for the surface sediments of the ECSS were generally within the range of $\delta^{15} \mathrm{~N}$ values for marine phytoplankton and terrigenous organic matter (Table 1). The ratios of TOC/TN for newly produced marine autogenic organic matter and terrigenous organic matter were 4-9 and $>12$, respectively (Meyers, 1994). The ratios of TOC/TN in the surface sediments of the ECSS were comparable with the values of newly
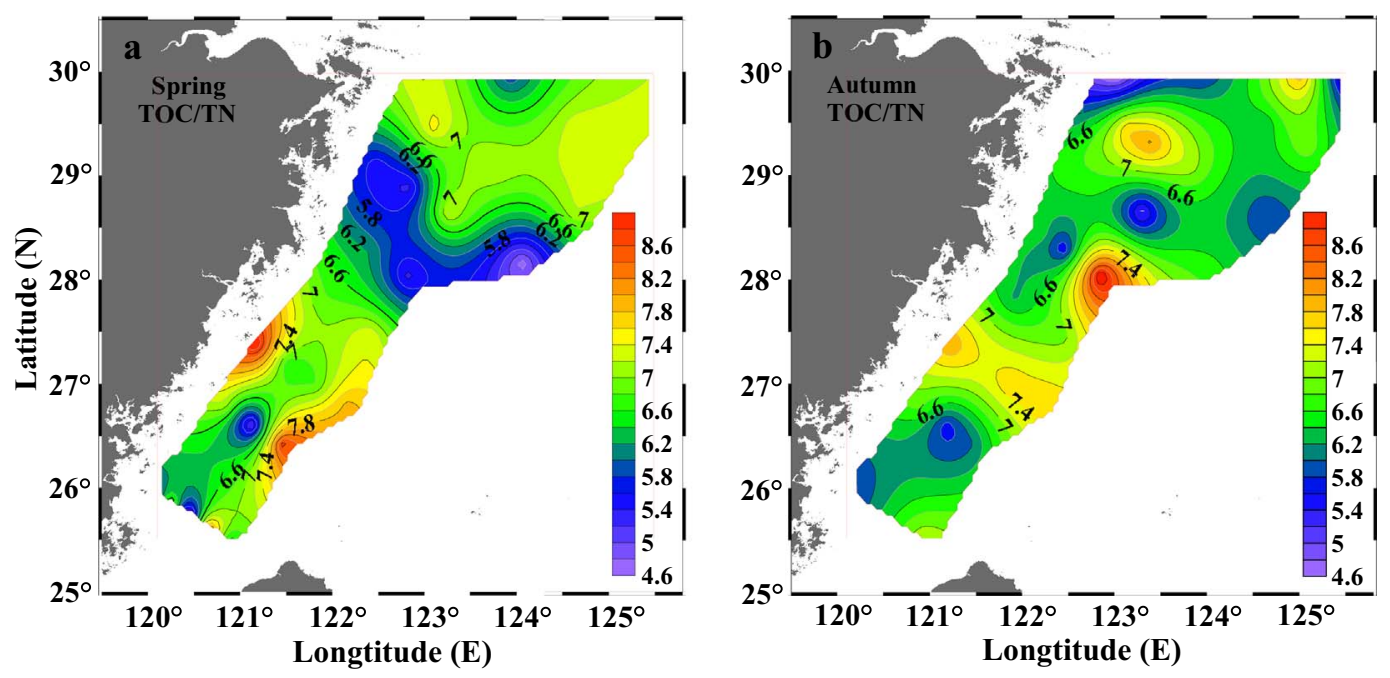

Fig. 6. Distributions of TOC/TN ratios in the surface sediments of the East China Sea shelf in spring and autumn. 
Table 1

Comparison of $\delta^{13} \mathrm{C}, \delta^{15} \mathrm{~N}$ and TOC/TN ratios in the sediments of the East China Sea shelf with related data.

\begin{tabular}{|c|c|c|c|c|c|c|}
\hline Location & Sampling time & & $\delta^{13} \mathrm{C}(\%)$ & $\delta^{15} \mathrm{~N}(\% 0)$ & $\mathrm{TOC} / \mathrm{TN}$ & Reference \\
\hline \multirow[t]{4}{*}{ East China Sea shelf } & May to Jun., 2014 & Range & -22.08 to -19.99 & $3.67-6.28$ & 4.69-9.12 & This study \\
\hline & & Mean & -21.35 & 4.60 & 6.74 & \\
\hline & Oct. to Nov., 2014 & Range & -21.97 to -20.10 & $4.60-6.13$ & $4.78-8.89$ & This study \\
\hline & & Mean & -21.00 & 5.32 & 6.73 & \\
\hline \multirow[t]{2}{*}{ Coastal areas of the East China Sea } & Jun., 2010 & Range & -21.8 to -20.7 & na & na & Cao et al. (2017) \\
\hline & Apr., 2006 & Range & -22.7 to -20.6 & na & na & Zhang et al. (2017) \\
\hline Sishili Bay & Nov., 2008 & Range & -22.7 to -21.6 & $5.4-6.5$ & 7.9-10.1 & Liu et al. (2012) \\
\hline Bohai Bay & 2006 & Range & -23.9 to -21.7 & na & $3.3-7.7$ & Hu et al. (2009) \\
\hline Changjiang Estuary & na & Range & -29.8 to -23.7 & $1.0-7.8$ & na & Liu et al. (2004) \\
\hline \multirow[t]{3}{*}{ Changjiang Estuary and adjacent sea } & $2006-2007$ & Range & -23.8 to -20.7 & na & na & Yang et al. (2015) \\
\hline & Jul. to Aug., 2011 & Range & -23.6 to -20.4 & na & $6.4-7.9$ & Li et al. (2014a) \\
\hline & & Mean & -22.5 & na & 7.1 & \\
\hline \multirow[t]{3}{*}{ Pearl River estuary } & Mar., 2005 & Range & na & na & $8.50-15.32$ & Zhang et al. (2010) \\
\hline & & Mean & -24.3 & na & na & \\
\hline & & Range & -25.19 to -23.33 & $3.73-6.57$ & $8.1-17.2$ & Zhang et al. (2009) \\
\hline \multirow[t]{3}{*}{ Marine organic matter } & & Range & -22 to -18 & $4-10$ & na & Gearing (1988) \\
\hline & & & & & & Cifuentes and Eldridge (1998) \\
\hline & & Mean & na & 6 & na & \\
\hline \multirow[t]{2}{*}{ Terrestrial organic matter } & & Range & na & -10 to 10 & na & Gearing (1988) \\
\hline & & Mean & na & 2 & na & \\
\hline Newly produced marine organic matter & & Range & na & na & $4-9$ & Meyers (1994) \\
\hline Newly produced terrestrial organic matter & & Range & na & na & $>12$ & Meyers (1994) \\
\hline \multirow[t]{2}{*}{ Terrigenous C3 plant } & & Range & -33 to -22 & na & na & Pancost and Boot (2004) \\
\hline & & Mean & -27 & na & na & O'leary (1988) \\
\hline \multirow[t]{2}{*}{ Terrigenous C4 plant } & & Range & -16 to -9 & na & na & Pancost and Boot (2004) \\
\hline & & Mean & -13 & na & na & \\
\hline Marine algae & & Range & -22 to -20 & na & na & O'leary (1988) \\
\hline
\end{tabular}

na: not available.

produced marine autogenic organic matter (Table 1), indicating that the organic matter in the surface sediments of the study area was mainly of marine autogenic origin.

Table 1 also shows the values of $\delta^{13} \mathrm{C}, \delta^{15} \mathrm{~N}$ and TOC/TN obtained in other studies. Generally, the observed $\delta^{13} \mathrm{C}$ values in this study were comparable to those found in the coastal areas of the East China Sea and the Sishili Bay, but higher than those of the Changjiang Estuary and the Pearl River Estuary. This indicated that the terrestrial influence on the ECSS was comparable with that on the Sishili Bay, but was weaker than that on the Changjiang Estuary and the Pearl River Estuary. Terrestrial OM primarily restricted within the estuary contributed much to that phenomenon (Hu et al., 2012). The $\delta^{15} \mathrm{~N}$ values and TOC/TN ratios in this study generally had wider ranges compared with those found in other areas shown in Table 1, which may be due to the larger study area of this study.

Elemental ratios of sedimentary organic matter can be used to evaluate nutrient enrichment situation (Ruiz-Fernández et al., 2002). In spring, TOC:OP and TN:OP ratios found in the surface sediments of the ECSS ranged from 52 to 205 (mean: 147) and from 7 to 33 (mean: 22), respectively; in autumn, they ranged from 52 to 238 (mean: 153) and from 7 to 35 (mean: 23), respectively. It was noticed that the values of them obtained in both seasons were generally above the Redfield ratio (C:N:P = 106:16:1; Redfield et al., 1963), suggesting that the C and $\mathrm{N}$ enrichment in the ECSS surface sediment was likely due to the transformation of $\mathrm{OP}$ to other geochemical phosphorus forms resulting from decomposition and/or early diagenesis (Meng et al., 2014; Zhou et al., 2016).

$\delta^{15} \mathrm{~N}$ values and TOC/TN ratios may change during organic matter decomposition processes, resulting in their limited use in the discrimination of the organic matter provenance (Thornton and MacManus, 1994; Wu et al., 2003). The values of $\delta^{13} \mathrm{C}$ are relatively stable during this process (Gearing et al., 1984; Ramaswamy et al., 2008; Gireeshkumar et al., 2013). In this study, TN and TOC concentrations and $\delta^{15} \mathrm{~N}$ values all showed obvious seasonal variations. The relationships between $\delta^{15} \mathrm{~N}$, TOC/TN and $\delta^{13} \mathrm{C}$ were studied to analyze whether $\delta^{15} \mathrm{~N}$, TOC/TN could be used to discriminate the source of organic matter. $\delta^{15} \mathrm{~N}$ did not show significant correlations with $\delta^{13} \mathrm{C}$ in spring, while it showed significant correlations with $\delta^{13} \mathrm{C}$ in autumn $\left(R^{2}=0.24,0.001<P<0.01\right.$; figure not shown). In both seasons, TOC/TN did not show significant correlations with $\delta^{13} \mathrm{C}$ (figure not shown). Therefore, only $\delta^{13} \mathrm{C}$ was used for further exploring the organic matter provenance.

We used a two end-member mixing model using $\delta^{13} \mathrm{C}$ as source markers to estimate the proportion of terrestrial and marine $\mathrm{OM}$ in the surface sediments of the ECSS (Sweeney et al., 1978; Westerhausen et al., 1993; Eadie et al., 1994). The estimated values were gained based on the following equation:

$\delta^{13} \mathrm{C}_{\text {measured }}=x \cdot \delta^{13} \mathrm{C}_{\text {terrestrial }}+(1-x) \cdot \delta^{13} \mathrm{C}_{\text {marine }}$

where $x$ is the fraction for the terrestrial end member, $(1-x)$ for the marine end member. According to the report of Yu et al. (2012) and Yang et al. (2015), the values of $\delta^{13} \mathrm{C}$ for the terrestrial end member and marine end member were assumed to be $-26 \%$ and $-20 \%$, respectively. This allowed for the calculation of the fraction of the terrestrialderived organic matter. In spring, the calculated percentages of the terrestrial-derived organic matter ranged from 0 to $34.6 \%$ with a mean of $22.4 \%$; in autumn, they ranged from $1.6 \%$ to $32.7 \%$ with a mean of $16.7 \%$ (Fig. 7). The average percentage of terrestrial organic matter was higher in spring than in autumn. In both seasons, the percentages of terrestrial organic matter generally decreased seaward (Fig. 7), indicating the decrease of terrigenous influence. This phenomenon was also reported by Yu et al. (2012). The percentages of the terrestrial organic matter in the ECSS were generally low compared with those found in the Changjiang Estuary (Yu et al., 2012; Yang et al., 2015), indicating the less influence of terrestrial input on the ECSS. The estimated percentages of marine OM in the surface sediments of the ECSS ranged from $65.4 \%$ to $100 \%$, which were comparable with the result reported by Cao et al. (2017) $(21 \%-86 \%)$.

The organic matter provenance in the surface sediments could reflect the dynamics of the overlying water. It could be noticed that there was an obvious tongue-shaped region with relatively low percentages of terrestrial OM $(<12 \%)$ in the northern part of the ECSS in both seasons (Fig. 7). This may be a reflection of the main intrusion pathway of the 

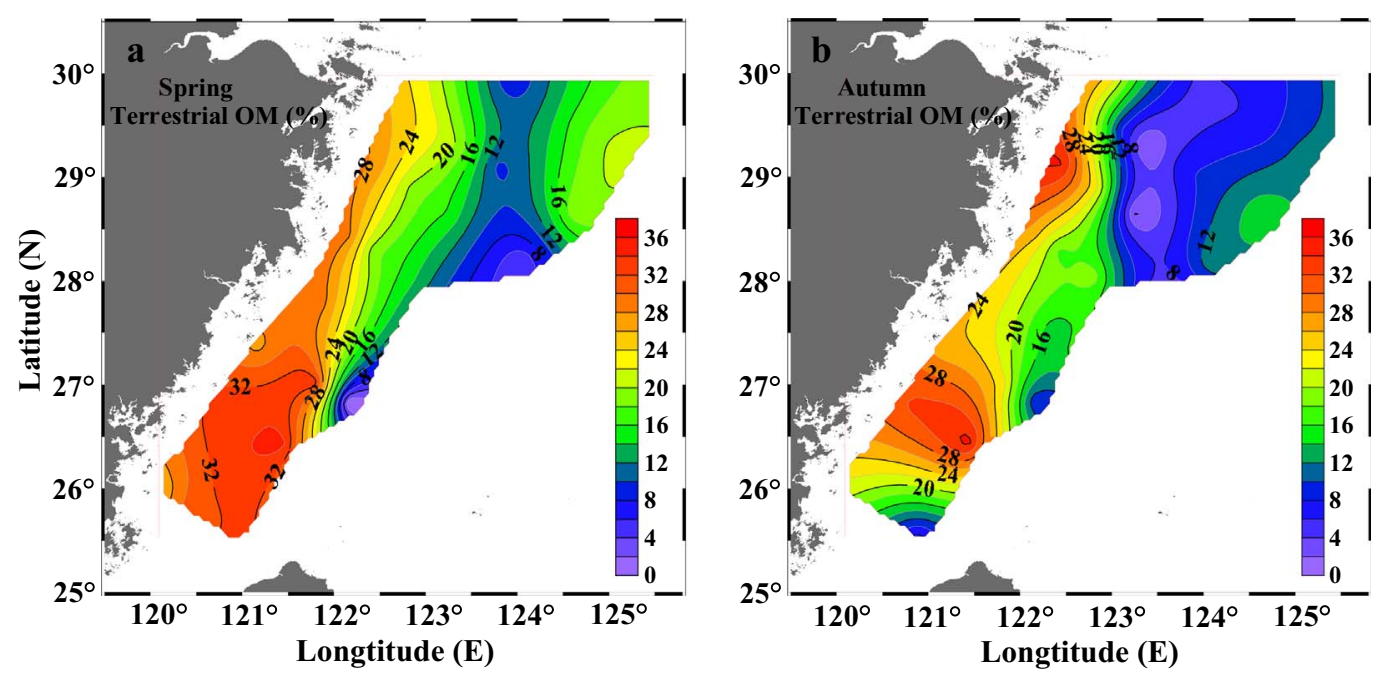

Fig. 7. The percentage distribution of terrestrial organic matter in the surface sediments of the East China Sea shelf in spring and autumn.

outer seawater. Previous studies have shown that the so-called Kuroshio Branch Current north of Taiwan could intrude into the ECSS to the east of the Changjiang Estuary (Su and Pan, 1987; Ichikawa and Beardsley, 2002; Yang et al., 2012; Wang and Oey, 2016). This may indicate that the intrusion of Kuroshio water had some influence on the distribution of organic matter in the surface sediments of the ECSS.

\subsection{Seasonal variations of biogenic elements and stable nitrogen isotopic compositions}

The organic matter produced by marine phytoplankton could settle down to the surface sediments. Part of them could be decomposed during settling or after the settlement (Andrieux and Aminot, 1997). This phenomenon could occur all the year round. The ECSS had high primary production during spring and summer (Chen et al., 2001, 2004; Rabouille et al., 2008; Li et al., 2014b), which could result in the accumulation rate higher than the decomposition rate of organic matter and then the increase of organic matter concentration in surface sediments. In autumn, the primary production in the ECSS decreased (Rabouille et al., 2008), resulting in the decomposition rate higher than the accumulation rate of organic matter and then the decrease of organic matter concentration in surface sediments. The values obtained in this study could prove this phenomenon. Obvious seasonal variations of TOC, TN, OP and $\delta^{15} \mathrm{~N}$ were observed in the surface sediments of the ECSS (Sections 3.1 and 3.2; Zhou et al., 2016). The average concentrations of TOC, TN and OP in autumn decreased obviously compared with those in spring, indicating the net decomposition of organic matter in the study area. This phenomenon was particularly clear in the northern part of the ECSS which was close to the Changjiang Estuary (Fig. 3; Zhou et al., 2016). The average $\delta^{15} \mathrm{~N}$ values were $4.60 \%$ in spring and $5.32 \%$ in autumn. This may indicate that the fractionation of $\mathrm{N}$ in organic matter occurred during the decomposition of organic matter. Wu et al. (2003) have expected that nitrogen cycling in the bottom of the ECSS water would create isotopically enriched nitrogen in the particulate organic matter through remineralization. Some of the particulate organic matter could settle down to the surface sediments. Therefore, the increase of average $\delta^{15} \mathrm{~N}$ values in the surface sediments of the ECSS in autumn found in this study was consistent with that expected by Wu et al. (2003).

The difference between the average concentrations of TOC, TN and OP ( $\Delta \mathrm{TOC}, \Delta \mathrm{TN}$ and $\Delta \mathrm{OP}$ ) in spring and autumn were $0.11 \%, 0.019 \%$ and $16.9 \mu \mathrm{g} \mathrm{g}^{-1}$, respectively. If these values were transformed into the same unit, the atomic ratio for $\Delta \mathrm{TOC}: \Delta \mathrm{TN}: \Delta \mathrm{OP}$ was $168: 25: 1$. This ratio was different from the Redfield ratio (106:16:1, Redfield et al., 1963), manifesting that the decomposition of organic matter in the surface sediments of the ECSS during spring, summer and autumn could provide more carbon and nitrogen for the growth of phytoplankton in the overlying water.

\section{Conclusions}

Previous studies focused on the spatial variation, abundance, age as well as burial of sedimentary organic matter in the Changjiang Estuary and its adjacent sea. In this study, we analyzed the biogenic element concentrations and stable carbon $\left(\delta^{13} \mathrm{C}\right)$ and nitrogen $\left(\delta^{15} \mathrm{~N}\right)$ isotopic compositions to study the distribution and seasonal variations of sedimentary organic matter (OM) in the surface sediments of the East China Sea shelf (ECSS). The values of $\delta^{13} \mathrm{C}$ presented obvious spatial distribution characteristics, with more negative values in the nearshore areas and relatively high values in the offshore areas. The distribution patterns and values of $\delta^{13} \mathrm{C}, \delta^{15} \mathrm{~N}$ and TOC/TN presented that organic matter in the surface sediments of the ECSS was predominantly marine autogenic and that the nearshore areas were influenced by terrigenous input to some extent. The average concentrations of TOC, TN and OP in autumn decreased obviously compared with those in spring, indicating the decomposition of organic matter during the investigation period. The increase of $\delta^{15} \mathrm{~N}$ values in autumn indicated the priority utilization of ${ }^{14} \mathrm{~N}$ by bacterial decomposition activity. The atomic ratio for $\Delta \mathrm{TOC}: \Delta \mathrm{TN}: \Delta \mathrm{OP}$ between spring and autumn was $168: 25: 1$, different from the Redfield ratio (106:16:1), indicating that the decomposition of organic matter in the surface sediments of the ECSS could provide more carbon and nitrogen for the growth of phytoplankton in the overlying water. A two end-member mixing model using $\delta^{13} \mathrm{C}$ as source markers was used to estimate the proportion of terrestrial and marine OM. The results showed that $0-34.6 \%$ of the sedimentary OM in the surface sediments of the ECSS was terrestrially derived. An obvious tongueshaped region with relatively high percentages of marine organic matter $(>88 \%)$ in the northern part of the ECSS is probably a reflection of the intrusion pathway of the outer seawater. Organic matter composition in sediments has close relationships with the dynamics of the overlying water. The combined study of sedimentary organic matter and the dynamics of the overlying water in future may be of great importance.

\section{Acknowledgments}

This study was financially supported by the Strategic Priority Research Program of the Chinese Academy of Sciences (XDA11020102), the National Natural Science Foundation of ChinaShandong Province Joint Fund for Marine Ecology and Environmental 
Sciences (U1606404) and the National Key Research and Development Plan - Sino-Australian Centre for Healthy Coasts (2016YFE0101500). The assistance of Baoxiao Qu, Changfeng Qu, Qidong Wang and Jiulong Zuo in the sample collection is greatly appreciated.

\section{References}

Andrews, J.E., Greenaway, A.M., Dennis, P.F., 1998. Combined carbon isotope and C/N ratios as indicators of source and fate of organic matter in a poorly flushed, tropical estuary: Hunts Bay, Kingston Harbour, Jamaica. Estuar. Coast. Shelf Sci. 46, 743-756.

Andrieux, F., Aminot, A., 1997. A two-year survey of phosphorus speciation in the sediments of the Bay of Seine (France). Cont. Shelf Res. 17, 1229-1245.

Cao, Y.Y., Xing, L., Zhang, T., Liao, W.H., 2017. Multi-proxy evidence for decreased terrestrial contribution to sedimentary organic matter in coastal areas of the East China Sea during the past 100 years. Sci. Total Environ. 599-600, 1895-1902.

Chen, Y.L.L., Chen, H.Y., Lee, W.H., Hung, C.C., Wong, G., Kanda, J., 2001. New production in the East China Sea: comparison between well-mixed winter and stratified summer conditions. Cont. Shelf Res. 21, 751-764.

Chen, Y.L.L., Chen, H.Y., Gong, G.C., Lin, Y.H., Jan, S., Takahashi, M., 2004. Phytoplankton production during a summer coastal upwelling in the East China Sea. Cont. Shelf Res. 24, 1321-1338.

Cifuentes, L.A., Eldridge, P.M., 1998. A mass and isotope balance model of DOC mixing in estuaries. Limnol. Oceanogr. 43, 1872-1882.

Cifuentes, L.A., Sharp, J.H., Fogel, M.L., 1988. Stable carbon and nitrogen isotope biogeochemistry in the Delaware estuary. Limnol. Oceanogr. 33, 1102-1115.

Dean, W.E., Arthur, M.A., Claypool, G.E., 1986. Depletion of ${ }^{13} \mathrm{C}$ in Cretaceous marine organic matter: source, diagenetic or environmental signal? Mar. Geol. 70, 119-157.

Eadie, B.J., Mckee, B.A., Lansing, M.B., Robbins, J.A., Metz, S., Trefry, J.H., 1994. Records of nutrient-enhanced coastal ocean productivity in sediments from the Louisiana continental shelf. Estuaries 17, 754-765.

Folk, R.L., 1974. The Petrology of Sedimentary Rocks. Hemphill Publishing, Austin, TX. Gearing, J.N., 1988. The use of stable isotope ratios for tracing the nearshore-offshore exchange of organic matter. In: Coastal-Offshore Ecosystem Interactions. Lecture Notes on Coastal and Estuarine Studies, vol. 22. pp. 69-101.

Gearing, J.N., Gearing, R.J., Rudrick, D.T., Requejo, A.G., Hutchins, M.J., 1984. Isotope variation of organic carbon in a phytoplankton based temperate estuary. Geochim. Cosmochim. Acta 48, 1089-1098.

Gireeshkumar, T.R., Deepulal, P.M., Chandramohanakumar, N., 2013. Distribution and sources of sedimentary organic matter in a tropical estuary, south west coast of India (Cochin estuary): a baseline study. Mar. Pollut. Bull. 66, 239-245.

Gong, G.C., Wen, Y.H., Wang, W.B., Liu, G.J., 2003. Seasonal variation of chlorophyll a concentration, primary production and environmental conditions in the subtropical East China Sea. Deep-Sea Res. II 50 (6-7), 1219-1236.

Goñi, M.A., Teixeira, M.J., Perkey, D.W., 2003. Sources and distribution of organic matter in a river-dominated estuary (Winyah Bay, SC, USA). Estuar. Coast. Shelf Sci. 57 (5-6), 1023-1048.

Graham, M.C., Eaves, M.A., Framer, J.G., Dobson, J., Fallick, A.E., 2001. A study of carbon and nitrogen stable isotope and elemental ratios as potential indicators of source and fate of organic matter in sediments of the Forth estuary, Scotland. Estuar. Coast. Shelf Sci. 52, 375-380.

Hodell, D.A., Schelske, C.L., 1998. Production, sedimentation, and isotopic composition of organic matter in Lake Ontario. Limnol. Oceanogr. 43 (2), 200-214.

Hu, L.M., Guo, Z.G., Feng, J.L., Yang, Z.S., Fang, M., 2009. Distributions and sources of bulk organic matter and aliphatic hydrocarbons in surface sediments of the Bohai Sea, China. Mar. Chem. 113 (3-4), 197-211.

Hu, L., Shi, X., Yu, Z., Lin, T., Wang, H., Ma, D., Guo, Z., Yang, Z., 2012. Distribution of sedimentary organic matter in estuarine-inner shelf regions of the East China Sea, implications for hydrodynamic forces and anthropogenic impact. Mar. Chem. 142-144, 29-40.

Ichikawa, H., Beardsley, R.C., 2002. The current system in the Yellow and East China Seas. J. Oceanogr. 58, 77-92.

Kang, X.M., Song, J.M., Yuan, H.M., Li, X.G., Li, N., Duan, L.Q., 2017. The sources and composition of organic matter in sediments of the Jiaozhou Bay: implications for environmental changes on a centennial time scale. Acta Oceanol. Sin. 36 (11), 68-78.

Kubo, A., Kanda, J., 2017. Seasonal variations and sources of sedimentary organic carbon in Tokyo Bay. Mar. Pollut. Bull. 114, 637-643.

Lamb, A.L., Wilson, G.P., Leng, M.J., 2006. A review of coastal palaeoclimate and relative sea-level reconstructions using $\delta^{13} \mathrm{C}$ and $\mathrm{C} / \mathrm{N}$ ratios in organic material. Earth Sci. Rev. 75, 29-57.

Li, X., Bianchi, T.S., Allison, M.A., Chapman, P., Mitra, S., Zhang, Z., Yang, G., Yu, Z., 2012. Composition, abundance and age of total organic carbon in surface sediments from the inner shelf of the East China Sea. Mar. Chem. 145-147, 37-52.

Li, D., Yao, P., Bianchi, T., Zhang, T.T., Zhao, B., Pan, H.H., Wang, J.P., Yu, Z.G., 2014a. Organic carbon cycling in sediments of the Changjiang Estuary and adjacent shelf: implication for the influence of Three Gorges Dam. J. Mar. Syst. 139, 409-419.

Li, H.M., Tang, H.J., Shi, X.Y., Zhang, C.S., Wang, X.L., 2014b. Increased nutrient loads from the Changiiang (Yangtze) River have led to increased harmful algal blooms. Harmful Algae 39, 92-101.

Liu, M., Hou, L.J., Xu, S.Y., OU, D.N., Jiang, H.Y., Yu, J., Gardner, W.S., 2004. Carbon and nitrogen stable isotopes as tracers to source organic matter in the Yangtze Estuary. Acta Geograph. Sin. 59 (6), 918-926 (In Chinese with English abstract).

Liu, D.Y., Shen, X.H., Wang, Y.J., Chen, Y.J., Li, L., 2012. Tracking the sources of organic matter in the surface sediments of Sishili Bay, northern Yellow Sea and the environmental implication. Acta Oceanol. Sin. 34 (5), 205-212 (In Chinese with English abstract).

Mariotti, A., Lancelot, C., Billen, G., 1984. Natural isotopic composition as a tracer of origin for suspended organic matter in the Scheldt estuary. Geochim. Cosmochim. Acta 48, 549-555.

Meng, J., Yao, P., Yu, Z.G., Bianchi, T.S., Zhao, B., Pan, H.H., Li, D., 2014. Speciation, bioavailability and preservation of phosphorus in surface sediments of the Changjiang Estuary and adjacent East China Sea inner shelf. Estuar. Coast. Shelf Sci. 144, 27-38.

Meyers, P.A., 1994. Preservation of elemental and isotopic source identification of sedimentary organic matter. Chem. Geol. 144 (3-4), 289-302.

Montoya, J.P., Horrigan, S.G., McCarthy, J.J., 1990. Natural abundance of ${ }^{15} \mathrm{~N}$ in particulate nitrogen and zooplankton in the Chesapeake Bay. Mar. Ecol. Prog. Ser. 65, 35-61.

O'leary, M.H., 1988. Carbon isotopes in photosynthesis. Bioscience 38, 328-336.

Owens, N.J.P., 1985. Variations in the natural abundance of ${ }^{15} \mathrm{~N}$ in estuarine suspended particulate matter: a specific indicator of biological processing. Estuar. Coast. Shelf Sci. 20, 505-510.

Pancost, R.D., Boot, C.S., 2004. The palaeoclimatic utility of terrestrial biomarkers in marine sediments. Mar. Chem. 92, 239-261.

Rabouille, C., Conley, D.J., Dai, M.H., Cai, W.-J., Chen, C.T.A., Lansard, B., Green, R., Yin, K., Harrison, P.J., Dagg, M., McKee, B., 2008. Comparison of hypoxia among four river-dominated ocean margins: the Changjiang (Yangtze), Mississippi, Pearl, and Rhône rivers. Cont. Shelf Res. 28 (12), 1527-1537.

Ramaswamy, V., Gaye, B., Shirodkar, P., Rao, P., Chivas, A., Wheeler, D., Thwin, S., 2008 Distribution and sources of organic carbon, nitrogen and their isotopic signatures in sediments from the Ayeyarwady (Irrawaddy) continental shelf, northern Andaman Sea. Mar. Chem. 111, 137-150.

Redfield, A.C., Ketchum, B.H., Richards, F.A., 1963. The influence of organisms on the composition of sea-water. In: Hill, M.N. (Ed.), The Sea. Vol. 2. Interscience Publisher, New York, pp. 26-77.

Ruiz-Fernández, A.C., Hillaire-Marcel, C., Ghaleb, B., Soto-Jiménez, M., Páez-Osuna, F., 2002. Recent sedimentary history of anthropogenic impacts on the Culiacan River Estuary, northwestern Mexico: geochemical evidence from organic matter and nutrients. Environ. Pollut. 118, 365-377.

Ruiz-Fuiz-Fernández, A.C., Hillaire-Marcel, C., Ghaleb, B., Soto-Jiménez, M., Páez-Osuna, F., 2002. Recent sedimentary history of anthropogenic impacts on the Culiacan River Estuary, northwestern Mexico: geochemical evidence from organic matter and nutrients. Environ. Pollut. 118, 365-377.

Sanil Kumar, K.S., Nair, S.M., Salas, P.M., Cheriyan, E., 2017. Distribution and sources of sedimentary organic matter in Chitrapuzha, a tropical tidal river, southwest coast of India. Environ. Forensic 18 (2), 135-146.

Su, J.L. (Ed.), 2005. The Oceanography in the Chinese Margin Sea. Ocean Press, Beijing (In Chinese).

Su, J., Pan, Y., 1987. On the shelf circulation north of Taiwan. Acta Oceanol. Sin. 5, 1-20.

Sweeney, R.E., Liu, K.K., Kaplan, I.R., 1978. Oceanic nitrogen isotopes and their uses in determining the source of sedimentary nitrogen. In: Robinson, B. (Ed.), Dep. Sci. Indust. Res. Bull., Sci. Inf. Div, pp. 9-26.

Tang, T.Y., Tai, J.H., Yang, Y.J., 2000. The flow pattern north of Taiwan and the migration of the Kuroshio. Cont. Shelf Res. 20, 349-371.

Thornton, S.F., MacManus, J., 1994. Application of organic carbon and nitrogen stable isotope and $\mathrm{C} / \mathrm{N}$ ratios as source indicators of organic matter provenance in estuarine systems: evidence from the Tay Estuary, Scotland. Estuar. Coast. Shelf Sci. 38, 219-233.

Vo $\beta$, M., Struck, U., 1997. Stable nitrogen and carbon isotopes as indicator of eutrophication of the Oder river (Baltic sea). Mar. Chem. 59, 35-49.

Wang, J., Oey, L.Y., 2016. Seasonal exchanges of the Kuroshio and shelf waters and their impacts on the shelf currents of the East China Sea. J. Phys. Oceanogr. 46, 1615-1632.

Westerhausen, L., Poynter, J., Eglington, G., Erlenkeuser, H., Sarnthein, M., 1993. Marine and terrigenous origin of organic matter in modern sediments of the equatorial East Atlantic: the $\delta^{13} \mathrm{C}$ and molecular record. Deep-Sea Res. 40, 1087-1121.

Wu, Y., Zhang, J., Li, D.J., Wei, H., Lu, R.X., 2003. Isotope variability of particulate organic matter at the PN section in the East China Sea. Biogeochemistry 65, 31-49.

Wu, Y., Fu, Y., Zhang, Y., Pu, X., Zhou, C., 2004. Phytoplankton distribution and its relation to the runoff in the Changjiang (Yangtze) Estuary. Oceanol. Limnol. Sin. 35 (3), 246-251 (In Chinese with English abstract).

Xing, L., Zhang, H., Yuan, Z., Sun, Y., Zhao, M., 2011. Terrestrial and marine biomarker estimates of organic matter sources and distributions in surface sediments from the East China Sea shelf. Cont. Shelf Res. 31, 1106-1115.

Yang, D., Yin, B., Liu, Z., Bai, T., Qi, J., Chen, H., 2012. Numerical study on the pattern and origins of Kuroshio branches in the bottom water of southern East China Sea in summer. J. Geophys. Res. 117, C02014. http://dx.doi.org/10.1029/2011JC007528.

Yang, B., Cao, L., Liu, S.M., Zhang, G.S., 2015. Biogeochemistry of bulk organic matter and biogenic elements in surface sediments of the Yangtze River Estuary and adjacent sea. Mar. Pollut. Bull. 96, 471-484.

Yu, J., Zhang, H., 2017. Source apportionment of sediment organic material in a semienclosed sea using Bayesian isotopic mixing model. Mar. Pollut. Bull. 119, 365-371.

Yu, Y., Song, J.M., Li, X.G., Duan, L.Q., 2012. Geochemical records of decadal variations in terrestrial input and recent anthropogenic eutrophication in the Changjiang Estuary and its adjacent waters. Appl. Geochem. 27 (8), 1556-1566.

Zhang, J., Wu, Y., Jennerjahn, T.C., Ittekkot, V., He, Q., 2007. Distribution of organic matter in the Changjiang (Yangtze River) estuary and their stable carbon and nitrogen isotopic ratios: implications for source discrimination and sedimentary dynamics. Mar. Chem. 106, 111-126.

Zhang, L., Yin, K.D., Wang, L., Chen, F.R., Zhang, D.R., Yang, Y.Q., 2009. The sources and accumulation rate of sedimentary organic matter in the Pearl River Estuary and 
adjacent coastal area, Southern China. Estuar. Coast. Shelf Sci. 85, 190-196.

Zhang, L., Chen, F.R., Yin, K.D., Lü, Y., Yang, Y.Q., Zhang, D.R., 2010. The characteristics and sources of surface sediments in the Pearl River Estuary and its adjacent shelves. J. Trop. Oceanogr. 29 (1), 98-103 (In Chinese with English abstract).

Zhang, H.L., Xing, L., Zhao, M.X., 2017. Origins of Terrestrial Organic Matter in Surface
Sediments of the East China Sea Shelf. 16 (5), 793-802.

Zhou, F.X., Gao, X.L., Yuan, H.M., Song, J.M., Chen, C.T.A., Lui, H.K., Zhang, Y, 2016. Geochemical forms and seasonal variations of phosphorus in surface sediments of the East China Sea shelf. J. Mar. Syst. 159, 41-54. 